3. Ромат Е. В. Реклама. Харьков: Студцентр, 2000. 480 с.

4. Черешнева Ю. Е. Промоушн печатных СМИ. Москва: Рипхолдинг, 2006. 262 с.

5. Leech G. N. English in Advertising: A Linguistic Study of Advertising in Great Britain. London: Longman, 1966. 210 p.

DOI https://doi.org/10.30525/978-9934-588-90-7-35

\title{
КОМУНІКАТИВНА СТРУКТУРА ВИСЛОВЛЮВАННЯ ТА ЗАСОБИ П̈Ї ВИРАЖЕННЯ В АНГЛІЙСЬКІЙ МОВІ
}

\author{
Гусейнова К. С. \\ викладач кафедри іноземних мов № 1 \\ Національний університет «Одеська юридична академія» \\ Бубнов Д. В. \\ викладач кафедри іноземних мов № 1 \\ Начіональний університет «Одеська юридична академія» \\ м. Одеса, Україна
}

Проблема аналізу засобів комунікативної організації висловлювання, незважаючи на відносну вивченість, залишається актуальною та продовжує привертати увагу дослідників.

Добре відомо, що в мовах світу існують кілька способів маркування компонентів комунікативної структури. Основними і універсальними 3 них прийнято вважати порядок слів та інтонацію. Комунікативна структура висловлювання найчастіше знаходить реалізацію саме у взаємодії фразової просодії та порядку слів, які утворюють в термінології Т. Є. Янко «линейно-акцентную структуру» [1].

Зіставлення ролі порядку слів та його взаємодії 3 інтонаційними засобами у визначенні комунікативного навантаження слова на матеріалі англійської мови становить інтерес тому, що англійська є мовою 3 жорстким або твердим порядком слів.

Основною функцією порядку слів в англійській мові $є$ граматична, вона висловлює певні синтаксичні відносини, а «вираз лексичного підмета та лексичного присудка $\epsilon$ менш важливим, ніж вираз граматичних відносин між словами» [2, с. 69]. Зазвичай в розповідному англійському реченні підмет - тема передує присудок - рема.

Оскільки базовим порядком слів в англійській мові є SVO (де S підмет, суб'єкт, V - дієслово - присудок, $\mathrm{O}$ - додаток, об'єкт), в незалеж130 
них від контексту висловлюваннях співвідношення актуального та граматичного членування збігається. Однак в умовах певної комунікативної ситуації, при актуалізації важливості того чи іншого слова, комунікативне членування може не збігатися 3 синтаксичним. В англійській мові при розбіжності актуального членування 3 синтаксичним використовуються, перш за все, інтонаційні засоби. У цьому випадку вони можуть стати основним маркером логічного предиката в судженні та «діяти спільно з лексичними та синтаксичними засобами, проте можливий випадок, коли інтонація є єдиним індикатором розподілу ступенів важливості відрізків висловлювання ...» [3, с. 6].

Під інтонаційними засобами вираження реми, нового, важливого мається на увазі фразовий наголос - найбільш сильний наголос у фразі, іiі інтонаційний центр. Слідом за Л. Р. Зіндер, ми приймаємо, що у фразовий наголос реалізуються всі інші види наголосів: синтагматичний, логічний та емфатичний [4, с. 275]. Переміщення фразового наголосу в одному реченні дає різне актуальне членування, таким чином реалізується одна з основних функцій інтонації - функція вираження відносин між елементами інтонаційних одиниць.

Поза контекстом нейтральним наголосом в англійській фразі не обов'язково виділено останнє знаменне слово.

В результаті аналізу матеріалів експериментів істотні розбіжності були виявлені і в позиції фразового наголосу в питально-відповідальних парах, де комунікативне навантаження слів в репліках-відповідях була визначена контекстом: в англійських прикладах інтонаційний центр був реалізований на елементі «нового», а не на останньому слові.

Наведені факти підтверджують провідну роль інтонаційних засобів в маркуванні компонентів комунікативної організації висловлювання в англійській мові.

При нейтральному порядку слів в розповідному реченні рема, або в разі впливу контексту «нове», знаходиться у фінальній позиції та отримує нейтральний наголос. Це є, по-перше, у висловлюваннях, комунікативна організація яких не залежить від контексту:

What happened?

John bought the newspaper.

По-друге, актуалізація доповнення «нового» фразовою наголосом в кінцевій позиції в англійській мові походить у відповідях на спеціальні питання, задані до прямого доповнення:

What did John buy?

John bought the newspaper. 
В англійській мові модель екстреного повідомлення реалізована, як правило, з фразовим наголосом на початковому підметі:

What happened?

Your brother arrived.

Такий порядок слів визначений також семантичною структурою фрази, а саме значенням предикативної ознаки.

Для речень, значення предикативної ознаки в яких інше (фізичної дії, мовної, інтелектуальної або емоційної активності та фізичного, емоційного чи інтелектуального стану), в цьому випадку характерна препозиція підмета -теми по відношенню до присудка - реми:

Maria shouted.

Однак семантична структура речення визначає таку актуалізацію компонентів актуального членування за допомогою порядку слів i фразового наголосу тільки в разі нейтрального контексту. У разі зміни комунікативного членування, елемент «нового» в англійській мові завжди буде в кінцевій, виділеній фразовим наголосом позиції, незалежно від значення дієслова:

Who is coming?

Antonio is coming.

У разі підмета - «даного», наприклад, в рамках наступної питальновідповідальної єдності, воно займе препозицію по відношенню до дієслова - присудка:

What about Susanna?

Susanna left.

В англійській мові у всіх випадках порядок слів залишиться незмінним, оскільки актуалізатором комунікативної значимості елементів служить місце реалізації фразового наголосу.

Дані про можливу реалізацію наголосу контрасту на нефінальном доповненні, так само, як і доповненні до функцій «нового», уривчасті та мізерні, а думки дослідників часто суперечливі.

Отже, фразовий наголос як основний засіб вираження комунікативної організації висловлювання використовується в англійській мові. Твердий порядок слів в англійській мові (інверсія підмета по відношенню до дієслова - присудка має місце в окремих випадках) компенсується можливістю фразового наголоса актуалізувати практично будь-яке слово фрази. Фразовий наголос в таких випадках, виділяє елемент «нового», що займає, як правило, фінальну позицію. Наголос контрасту може бути реалізовано як інтонаційними засобами (в нефінальной позиціі), так i взаємодією інверсионного порядку слів і фразового наголосу в кінці висловлювання. 
Навчання вмінню обрати потрібні мовні засоби для реалізації мети висловлювання представляється надзвичайно важливим, оскільки воно пов'язане $з$ підвищенням прагматичної компетенції мовця нерідною мовою.

\title{
Література:
}

1. Янко Т. Е. Коммуникативные стратегии русской речи. М. : Языки славянской культуры, 2001. 384 с.

2. Смирницкий А. И. Синтаксис английского языка. М. : Изд-во литературы на иностр. яз., 1957. 285 с.

3. Торсуева И. Г. Интонация и смысл высказывания. М. : Наука, 1979. $112 \mathrm{c}$.

4. Зіндер Л. Р. Общая фонетика. М.: Высшая школа, 1979. 312 с.

5. Ніколаєва Т. М. «Экстренное введение в ситуацию»: особый вид просодического выделения // Теория языка. Методы его исследования и преподавания. Л., 1981. С. 182-187.

6. Zubizarreta M. L. Prosody, Focus, and Word Order. Cambridge: MIT Press, 1998. 153 p.

DOI https://doi.org/10.30525/978-9934-588-90-7-36

\section{КОМІЧНЕ ПОРТРЕТУВАННЯ ПЕРСОНАЖІВ Е. А. ПОУ ТА М. ГОГОЛЯ: МОВНО-СТИЛІСТИЧНІ ПРІОРИТЕТИ}

\author{
Долгушева О. В. \\ кандидат філологічних наук, \\ доцент кафедри англійської мови та методики ії викладання \\ Центральноукраїнський державний педагогічний університет \\ імені Володимира Винниченка \\ м. Кропивницький, Украӥна
}

Сучасна парадигма філологічних розвідок вирізняється антропоцентричним спрямуванням своїх наукових пошуків. Образ людини як творця і носія мови, у якому моделюється специфіка індивідуальної та колективної свідомості, віддзеркалюються світоглядні орієнтири, емоційні стани й інтелектуальні прояви тощо, постає об'єктом багатьох наукових пошуків. У художніх творах портретні образи демонструють авторський погляд на певні суспільно вагомі риси особистостей, а також розкривають потенціал лінгво-стилістичних засобів тієї чи іншої мови. 